\title{
What Price History: Politics, Commercialism, and Urban Preservation
}

Theodore J. Karamanski

Loyola University Chicago, tkarama@luc.edu

Follow this and additional works at: https://ecommons.luc.edu/history_facpubs

Part of the History Commons, and the Urban Studies and Planning Commons

Author Manuscript

This is a pre-publication author manuscript of the final, published article.

\section{Recommended Citation}

Karamanski, Theodore J.. What Price History: Politics, Commercialism, and Urban Preservation. Journal of Urban History, 44, 5: 1018-1024, 2018. Retrieved from Loyola eCommons, History: Faculty Publications and Other Works, http://dx.doi.org/10.1177/0096144218775085

This Article is brought to you for free and open access by the Faculty Publications and Other Works by Department at Loyola eCommons. It has been accepted for inclusion in History: Faculty Publications and Other Works by an authorized administrator of Loyola eCommons. For more information, please contact ecommons@luc.edu. c) (†) $\ominus$

This work is licensed under a Creative Commons Attribution-Noncommercial-No Derivative Works 3.0 License. (C) Theodore Karamanski 2018 


\section{What Price History: Politics, Commerialism, and Urban Preservation}

James M. Lindgren (2014). Preserving South Street Seaport: The Dream and Reality of a New York Urban Renewal District. New York: New York University Press, $370+$ xivpp., illustrations, notes, index, \$35.00 cloth.

Yue Zhang (2013). The Fragmented Politics of Urban Preservation: Beijing, Chicago, Paris. Minneapolis: University of Minnesota Press, pp. xxviii, 201, illustrations, bibliography, index, \$75.00 cloth, \$25.00 paper.

Theodore J. Karamanski, Loyola University Chicago

Key words: Historic - preservation - urban redevelopment - maritime history

Historic preservation is the child of the city. In North America the United States Conference of Mayors served as midwife to the birth of the modern historic preservation movement when in January 1966 it issued the report With a Heritage So Rich. The report's authors argued that in losing historic buildings and districts to urban renewal America was severing a vital link to the past. "Connections between successive generations of Americans - concretely linking their ways of life - are broken by demolition. Sources of memory cease to exist." Part coffee-table book and part policy proposal, the volume laid the foundation for the 1966 National Historic Preservation Act, whose fiftieth anniversary is being celebrated this year. Even before these decisive actions Jane Jacobs made the need to preserve the historic fabric of the city a key element in her critique The Death and Life of Great American Cities. For Jacobs old buildings, historic and otherwise, were also key to maintaining the low rent commercial real estate base that was vital to growth of new businesses. "Cities need old buildings," she wrote, "so badly it is probably impossible for vigorous streets and districts to grow without them." Together Jacobs and the U.S. Conference of Mayors laid the foundation for historic preservation in North America, but they also laid bare a conflict that emerges at some point in every urban preservation enterprise. Is historic preservation a piece in a complex urban redevelopment strategy or is historic preservation an end unto itself? ${ }^{1}$ 
The two books under review in this essay both grapple with the question of how the economic and political imperatives of urban redevelopment mesh with the goal of preserving historic buildings and distinctive urban landscapes. There is certainly no more problematic and controversial aspect of our public history than historic preservation. When historians are doing community history projects or conducting oral narratives with the public, they make a conscious effort to share authority with their audience and the subjects of their research. In historic preservation public historians make plans and place restrictions on other people's property, something which never fails to engender protest. Much of what goes on in their field of preservation challenges the Lockean premises upon which liberal democratic society rests. The outright taking or limiting of private property rights, therefore, ensures that historic preservation is the branch of public history that is most enmeshed in political and legal controversy.

Most major urban areas have had seminal contests between property rights and heritage that have shaped the public perception of and municipal support for historic preservation. Typically these contests have been decided in favor of property rights, and preservationists have embraced their defeats as symbols around which to rally public support for the broader cause of saving distinctive elements of the urban landscape. In New York the failure to save the Pennsylvania Station and in Chicago the destruction of Louis Sullivan's Stock Exchange Building spurred municipal government to pass landmark preservation ordinances. In these cities and others around the world historic preservation legislation has been successful in "saving" great works of architectural beauty or significance.

Yet, what does it mean to save or preserve an urban structure? This question lays bare another layer of controversy, one that is inherent in historic preservation. Historians save documents, works of art, or artifacts in climate-controlled facilities where light and temperature are carefully monitored. Historic preservation takes place in a living landscape exposed to all the ravages of nature and pollution. 
This means that "saving" structures requires intervention from something as benign as tuck-pointing masonry to tearing out decayed historic materials and replacing them with the new. It is these necessary interventions that make historic preservation the most costly aspect of public history and the one that is inevitably embroiled in the market place. Since the nineteenth century, preservationists have argued over how much intervention can take place before the value of what was historic is lost and how much change is necessary in order to make a structure useful in a commercial sense. This issue is even more problematic when what is at stake are not single buildings but the social milieu of a distinctive urban neighborhood, where lifestyle and cultural atmosphere are among the values to be "saved." The challenge cities face determining what is to be preserved and how preservation is to be defined is at the heart of the otherwise very different books here under review.

Yue Zhang is a political scientist at the University of Illinois, Chicago, who was drawn to the subject of historic preservation by the rapid and extreme transformation of Beijing. Places he had known in his youth vanished under the wrecking ball and within a decade his hometown had been rendered unfamiliar. He set out to study how other cities handled historic preservation in order to better understand what had happened in Beijing. His vehicle for doing this is three case studies of how political power has shaped the urban landscape in Beijing, Chicago, and Paris. These cities were chosen because they each have a prominent place in the history of architecture and design, and each are dynamic enough to face the "constant challenges of creative destruction." 2

While Zhang allows that historic preservation issues engage a broad range of actors, he believes that the actual implementation of preservation is shaped by the fragmented power structure of urban government. Therefore, the theory of political fragmentation controls the structure and content of the case studies. Urban historians are generally familiar with an institutional approach to government out of which this approach grows. The logic of political fragmentation studies is to explore the fragmented nature of interagency relationships. Zhang identifies three different types of political fragmentation: 
functional fragmentation, territorial fragmentation, and intergovernmental fragmentation. Conveniently each of these types of fragmentation is characterized in the history of preservation in the selected cities.

For the preservationist the most interesting and troubling of the cities studied by Zhang is his former hometown of Beijing. Here what is called historic preservation is used by the local government primarily as a tool to promote economic growth with a secondary desire to improve the international image of the Chinese capital. Much of the story Zhang tells revolves around the preparation for the 2008 Summer Olympics. Beijing boasts an urban history dating back more than 3,000 years. As the capital of five different imperial dynasties, it was at the middle of the twentieth century the repository of some of the finest examples of Chinese architecture and its integrity of design prompted one prominent urban planner to judge it "possibility the greatest single work of man on the face of the earth."

But no dynastic change so impacted the face of the city as the arrival of Mao-Zedong and the Communist Party. Inherently anti-urban in their orientation and determined to put a socialist stamp on the decadent city, Communist leaders destroyed much of the historic center of the old city. The city walls were demolished and the iconic gate structures that had been symbols of old Beijing were removed to make way for highways and subways. At the same time the urban core was gutted and replaced with bureaucratic buildings and heavy industry plants. The city's older neighborhoods deteriorated through neglect and misuse. Once grand courtyards houses were crowded with numerous families - none of whom had a stake in the maintenance of the property. This set the stage for periodic urban renewal campaigns that leveled whole neighborhoods. In the 1990 s the rhetoric of socialism was exchanged for profit-motivated real estate development and bull-dozing accelerated. In less than fifty years more than two-thirds of the historic fabric of Beijing had been replaced by shopping centers, banal glass office towers, and marble clad luxury apartment buildings. The initial slogan of the Beijing Olympic proposal was "New Beijing, Great Olympics." Fortunately by 2001 critics within and outside China 
expressed concern that it was old Beijing that needed attention and in response the protection of cultural heritage appeared to emerge as a twenty-first century priority.

Because Beijing is the capital of a centralized state one would think that what passed for an historic preservation policy would be set by the national government. Instead, Zhang found that the real decision making was done by no less than forty-six municipal bureaucracies each with narrowly proscribed areas of authority. This is what he described as "Functional fragmentation." Among this thicket of bureaus were professionals who designated thirty historic districts in the city and which proposed preservation plans for those areas. At that point, however, preservation professionals stepped back and had no role in implementing those plans. While fragmentation frustrated true historic preservation, the Chinese bureaucracy had no trouble uniting for new construction projects that used heritage to justify new development. Zhang narrates the fate of the Qianmen Historic Preservation District, a densely inhabited district with 60,000 residents with diversified working-class commercial streetscapes. With the goal of creating a Chinese Champs-Elysees, officials tore down historic buildings and replaced them with modern copies. Original residents and business were moved out and worldrenowned luxury retailers set up shop in the faux-historic structures. This heavy-handed approach was justified as necessary because of the looming deadline of the Olympic opening ceremony. The result was gentrification, high rents for those elites who held property leases, enhanced revenue for the district government, and the displacement of the local population.

Paris, like Beijing, is also the national capital of a centralized state. Indeed, until quite recently Paris was completely under the administration of the national state. Protecting the historic ambience of the city was a patriotic priority for the central government. Paris did not elect its first mayor until 1977 when Jacques Chirac was voted into office. Local concern that the city was in danger of death by museification was then given voice and municipal administrations argued for a more growth friendly and comprehensive approach to preservation planning. This set the stage for what Zhang calls 
"intergovernmental fragmentation." In one case study involving the 2002 renovation of Chateau Rouge, a neighborhood of African immigrants, Zhang describes the city's efforts to purposefully gentrify the area, and alter its ethnic and economic population. The national government allowed Parisian authorities to proceed because they saw this as only a local matter. Whereas in 2006 when the city government proposed Paris's first comprehensive urban development plan, there was an immediate negative reaction. The plan proposed to "give historic buildings new life through renovation and adaptive reuse" as well as facilitate new design in historic neighborhoods. The French government saw this as a threat to the national patrimony and it sued local officials in the Administrative Court of Paris. The controversy revealed that the French government had only selectively ceded authority over heritage to the Parisian government and that at best historic preservation in city had become what Zhang calls a "joint venture" with the French government intervening any time a site of national interest was impacted. ${ }^{3}$

Because of Chicago's long tradition of urban boss politics, particularly under mayoralties of Richard J. Daley and later his son Richard M., it would be natural to assume that historic preservation as with other aspects of urban government would be under centralized control. Like in the case of Beijing, however, Zhang argues that fragmentation not centralization best characterizes urban development in Chicago. The controlling factor here, however, is not a welter of competing bureaus but the feudal-like power of city alderman, the infamous "Grey-Wolves" of the city council. Like medieval kings Chicago mayors could be the big city boss only by respecting the prerogatives of an alderman to control developments within his or her wards, particularly in the areas of zoning and building permits. This unofficial devolution of power is known as "aldermanic privilege." In return, the loyal vassals of the city council would approve the mayor's budget, support any City Hall pet projects, and most important turnout the voters in their ward to reelect the mayor and his approved municipal slate. Zhang dubs this distribution of political power as "territorial fragmentation." The territorial issue is all the more 
significant because Chicago has a strong tradition of neighborhood identity reinforced by ethnic, racial, and economic segregation. Yet aldermanic wards do not respect neighborhood boundaries as those districts are gerrymandered after each federal census to ensure equal population size. This mismatch between community boundaries and legislative wards is a second type of territorial fragmentation that influences historic preservation in Chicago.

Zhang illustrates the impact of "territorial fragmentation" through two examples of historic preservation initiatives in Chicago minority communities, the Mexican-American neighborhood of Pilsen and the historic heart of African-American Chicago, Bronzeville. Both are communities with income levels below the city-wide average and both had a large stock of late nineteenth and early twentieth century housing, which made them ripe for historic preservation and vulnerable to gentrification.

In Pilsen the alderman supported the process of creating a National Register of Historic Places District. He was aided in this effort because the boundaries of his ward coincided with the recognized margins of the Pilsen community. Although there was some controversy over who would reap the economic benefits of historic designation, the alderman, in alliance with Pilsen property owners, prevailed.

In the case of Bronzeville several community based organizations supported the ambitious goal of having their neighborhood named a National Heritage Area because of the national impact of its historic black businesses, prominent African-American residents, and central role in the development of jazz and blues music. Bronzeville, however, was split between three wards and none of the alderman were keen on supporting the community organization leaders whom they regarded as up-and-coming political rivals. This split between community leaders on one hand and the ward bosses ensured the heritage area proposal would be frustrated. On the other hand, aldermen were supporters of more modest preservation initiatives that were confined to their respective wards. Zhang cites the example 
of a proposal to create a $43^{\text {rd }}$ Street Chicago Blues District anchored by the Checkerboard Lounge, the base of Muddy Waters, "the Father of Chicago Blues." The alderman supported the plan but insisted the location be moved to $47^{\text {th }}$ Street where her office was located and where there was a more substantial commercial district. This helped those businesses but left the genuine historic structures to languish. ${ }^{4}$

Zhang's analysis of Chicago is generally astute and well-illustrated by his two examples. He does, however, underplay the power of City Hall and the business community in preservation planning in the Windy City. Due to vacancies caused by indictments or promotion to other offices, a considerable number of Chicago alderman are actually appointed by and beholding to the mayor. With a number of aldermen in the mayoral pocket, City Hall can and does override aldermanic privilege when it clashes with their priorities, as when in 2008 Mayor Richard M. Daley forced through the City Council approval of a plan to build a Children's Museum in Grant Park. Also, unlike Beijing Chicago does have a centralized historic preservation body, the Commission on Chicago Landmarks. In 1998 after the Bronzeville National Heritage Area was frustrated the Commission created the Black MetropolisBronzeville Historic District. This theme district carried with it much stronger protection than a heritage area would have brought, although it included only nine structures in the heart of Chicago's old black downtown. The Historic Chicago Bungalow Initiative, which Zhang mentions, was a Richard M. Daley initiative which has led to the creation of eleven large neighborhood historic districts that overlap ward boundaries. Indeed nearly half of Chicago is now blanketed by various historic districts and in some cases City Hall played a much more important role than local alderman in their creation. ${ }^{5}$

Zhang's concern for the governmental dynamics behind urban preservation leaves out the role played by market economics in each of his three cities. For example, in the case of Chicago the "territorial fragmentation" brought by aldermanic privilege is much less a factor in urban preservation than urban economic development. National Register Historic Districts that bring with them the tax breaks that can fuel gentrification do not require aldermanic approval. While the Commission on 
Chicago Landmarks can comment on such nominations, it cannot stop them. Such nominations are judged by a state-appointed board of preservation professionals and community activists and finally by the National Park Service. Since the 1980s real estate developers in Chicago and much of the country have been the drivers of many National Register projects. The gentrification of the once gritty Uptown community in Chicago is a case in point where aldermanic opposition was unable to stop the creation of historic districts that facilitated the displacement of many working-class residents and the generation of higher property values. As in the case of Beijing the dictates of the market in American cities can be as important as the political dynamic Zhang analyzes so well. Zhang's case studies are useful for any historian of twenty-first century urbanism but historic preservation's complex cast of characters must include the many private interests and organizations that compete with government to shape the heritage of the modern city. ${ }^{6}$

The saga of New York City's South Street Seaport District of Lower Manhattan is a classic case of the interplay of community and interest based popular movements, with for-profit corporations, and Zhang's fractured urban political networks. James M. Lindgren, a Professor of History at SUNY Plattsburgh and an accomplished historian of preservation in America, has crafted an epic tale of the perils of public history. His cast of characters includes salty tall ship captains, fish mongers, the fallen angel of New York liberalism Mayor John Lindsey, World Trade Center builder David Rockefeller, Mafia capo Joseph Cantalupo, folk singer Pete Seeger, the Rouse Corporation of festival market fame, the State of New York, the Port Authority, preservation purist Ada Louise Huxtable, the Howard Hughes Corporation, Robert Moses, Jane Jacobs and literality hundreds of museum professionals and dedicated volunteers who all contested over the heritage of South Street Seaport. Even Donald Trump makes a cameo appearance and typically he threatens to sue a detractor of his vision for lower Manhattan. Lindgren's history is colorful, dense with detail, yet always interesting and valuable to student of urban preservation, development, and maritime history. ${ }^{7}$ 
The South Street story requires a dense and intricately plotted narrative because it embraces such a wide and varied range of heritage issues from historic ship preservation, museum management, and local history to commercialization, real estate development, and tourism. The South Street saga began in the optimistic "people power" days of the 1960s. The demolition of the Pennsylvania Station and its beaux arts splendor inspired public outrage and preservation activism. One focus of concern was a decrepit commercial block amid the Fulton Street Fish Market. Schermerhorn Row had been built at the time of the War of 1812 and was one of New York and the nation's best surviving examples of Federal style commercial architecture. What began as an effort to save this block of old counting houses soon morphed into a bolder plan to protect the entire old seaport area and evoke the maritime heyday of the nineteenth century by assembling a row historic ships at its East River piers. From its inception the boosters of South Street embraced Daniel Burnham's dictum "make no little plans." New York Mayor John V. Lindsey (1966-73) was swept along with their enthusiasm and in an unprecedented and ultimately harmful decision designated the fledgling maritime history museum the official urban renewal sponsor for twelve-block section of lower Manhattan. However, the cash-strapped city offered no funds to help the museum actually acquire the expensive land it was charged with managing. South Street was lauded as a new type of cultural institution where commerce and history could be melded to create a people friendly place for New Yorkers to reengage with the city and its history.

In its youth, with its naively ambitious creators at its helm, South Street accomplished great things. The smelly old waterfront came alive with a million annual visitors attracted to folk concerts and the innovative Sidewalk History Project that epitomized the ideal of that era, "a museum without walls." Membership surged to 25,000 making it the city's largest historical institution. The Pioneer Marine School taught wayward inner-city youth maritime job skills that led to real employment at East Coast marinas. They took the lead in the New York's Bicentennial celebration by organizing Operation Sail '76 a stunning parade of 228 sailing ships. Perhaps most remarkably within a few short years, they had 
assembled along the waterfront their own fleet of eleven historic vessels-the largest such collection in the world. Yet, so much of what was attempted was beyond the financial reach of a young cultural organization. A classic example of this was the museum's attempt to restore the Wavertree and Peking, two late nineteenth century square rigged sailing ships, each of which required millions of dollars of ongoing maintenance. Together they were the two largest museum objects ever brought to New York. The management of the two rusty hulks challenged South Street's understanding of the preservation enterprise. On one hand, ships are utilitarian objects meant to be sailed and only under sail can their true historical nature be understood. Yet to meet modern maritime regulations the vessels would have to be substantially changed with historic features replaced. For decades South Street struggled to resolve this dilemma all the while trying to keep up with the basic maintenance necessary to literally keep its historic vessels afloat. By the late 1970s the museum's financial difficulties and its stalled redevelopment agenda led to the removal of many of the maritime history buffs who first built the institution and their replacement by allegedly clear-eyed men of business.

The new South Street Seaport of the 1980s was characterized by the development of a waterfront shopping mall by the James Rouse Company and the gradually atrophy of activities related to maritime history or crafts. The mall was supposed to fund history but instead it pushed it to the margins while failing to meet any of the grandiose economic benefits promised by the developers. In the 1990s the seaport board tacked back to heritage with new exhibits and the restoration of historic structures, but its attempts to be both a real estate manager and cultural organization never harmonized. The 9-11 attacks and later super storm Sandy were body-blows that knocked the museum to the canvas and from which it has yet to recover. James Lindgren concludes his narrative in 2014 with the Seaport's exhibits closed and its future very much in doubt, as it remains so in 2016. He celebrates the Seaports undoubted success in preserving much of New York's maritime heritage but in the end his is a cautionary tale of commerce crowding out culture. 
Lindgren's Seaport saga like Zhang's Beijing case study illustrates the importance of market conditions in determining the direction of historic preservation. When real estate values were depressed in lower Manhattan in the late 1960s and 1970s and the city was bankrupt, its politicians empowered the Seaport's idealistic founders. As values rose the Seaport district like the old city of Beijing became the catspaw of developers. Under such conditions saving historic structures let alone districts requires astute management of the fragmented landscape of urban politics. More sobering, however, are the lessons of Paris's Chateau Rouge, Chicago's Uptown, Beijing's Qianmen district and especially the fate of the New York's South Street. Historic buildings can be saved yet it is much harder when pressured by the market to preserve the unique cultural quality of a place, its atmosphere, and distinctiveness. As public historians we understand preservation requires capital and the sobering truth of our job is to manage what price history will pay.

\footnotetext{
${ }^{1}$ United States Conference of Mayors, Special Committee on Historic Preservation, With a Heritage So Rich (New York: Random House, 1966), p.xv; Jane Jacobs, The Death and Life of Great American Cities (New York: Vintage Books, 1961), p.187.

${ }^{2}$ Yue Zhang, The Fragmented Politics of Urban Preservation: Beijing, Chicago, and Paris (Minneapolis: University of Minnesota Press, 2013), xv.

${ }^{3}$ Zhang, Fragmented Politics of Urban Preservation, 120, 144.

${ }^{4}$ http://chicago-architecture-jyoti.blogspot.com/2010/03/blues-district-bronzeville.html, accessed May, 2016.

${ }^{5}$ http://www.chicagobungalow.org/bungalow-communities/historic-districts/creating-chicago-bungalow-historicdistricts, accessed May, 2016; Theodore J. Karamanski, “History, Memory, and Historic Districts in Chicago," The Public Historian, Vol. 32 No. 4 (Fall 2010), 33-41.

${ }^{6}$ Larry Bennett, Neighborhood and Politics: Chicago and Sheffield, (New York: Garland, 1997), 220-24; Martin Tangora, Sheridan Park Historic District, National Register of Historic Places Form, Section 8, p.3; David Burnham, "Making History," The Reader, Vol. 15, No.43 (25 July 1986), 18.
} 
${ }^{7}$ In the mid-1980s Donald Trump proposed to build the world's tallest building, an office-hotel complex, at the South Street site. When the Chicago Tribune called it "one of the silliest things anyone could inflict on New York" the Donald sued the newspaper for libel to the tune of $\$ 500$ million. Trump was, however, not able to secure the building site. Three decades later he built a new high-rise tower with a giant "Trump" sign across from the Chicago Tribune building.

\section{Biographical Citation}

Theodore J. Karamanski is a Professor of Public History at Loyola University Chicago. He is a heritage preservation consultant and the author of numerous books on public or Midwest history, most recently Civil War Chicago: Eyewitness to History with Eileen M. McMahon (Athens: Ohio University Press, 2014). 